\title{
Biomass and abundance of termites in three remnant areas of Atlantic Forest in northeastern Brazil
}

\author{
Alexandre Vasconcellos ${ }^{1}$ \\ ${ }^{1}$ Departamento de Botânica, Ecologia e Zoologia, Centro de Biociências, Universidade Federal do Rio Grande do Norte, 59072-970 Natal-RN, Brazil. \\ avasconcellos@cb.ufrn.br
}

\begin{abstract}
Biomass and abundance of termites in three remnant areas of Atlantic Forest in northeastern Brazil. Termite biomass and abundance were estimated in three remnant areas of Atlantic Forest in northeastern Brazil: Reserva Biológica de Pedra Talhada-RBPT (Alagoas State), Parque Estadual Dois Irmãos-PEDI (Pernambuco State), and Área de Proteção Ambiental Mata do Buraquinho-APMB (Paraíba State). A quantitative sampling of the termite assemblages present on trunks and leaf litter, in nests, and in the soil was undertaken during the months of June and July (rainy season) and November and December (dry season) of 2000. Thirty seven species of termites were encountered and quantified in the three remnant forest areas. The termite biomass varied from 10.09 to $11.30 \mathrm{~g}$ (fresh weight) $/ \mathrm{m}^{2}$ and abundance varied from 4911 to 5663 individuals $/ \mathrm{m}^{2}$. The subfamily Nasutitermitinae was dominant in terms of the number of species, biomass, and abundance. The soil-feeders were the most abundant at the three sites, while wood-feeders had the largest biomass at least at the PEDI and APMB sites. Among the microhabitats quantified, termites were most frequently encountered in the soil, being most heavily concentrated at depths of $0-20 \mathrm{~cm}$. Two species stood out in terms of their biomass and abundance: Embiratermes parvirostris Constantino, on the soil, and Nasutitermes corniger (Motschulsky), on decomposing trunks and in nests. Estimates of biomass and abundance suggest that termites play an important role in the decomposition of the plant necromass in remnant forest areas of the Atlantic Forest in northeastern Brazil.
\end{abstract}

KEYWORDS. Isoptera; Neotropical Region; nest; quantitative survey; vertical distribution.

RESUMO. Biomassa e abundância de térmitas em três remanescentes de Mata Atlântica do Nordeste brasileiro. A biomassa e a abundância de térmitas foram estimadas em três remanescentes de Mata Atlântica do Nordeste brasileiro: Reserva Biológica de Pedra Talhada-RBPT (Estado de Alagoas), Parque Estadual Dois Irmãos-PEDI (Estado de Pernambuco) e Área de Proteção Ambiental Mata do Buraquinho-APMB (Estado da Paraíba). Amostragens quantitativas da assembléia de térmitas foram realizadas em troncos, folhiço, ninhos e solo nos meses de junho e julho (estação chuvosa) e novembro e dezembro (estação seca) de 2000. Trinta e sete espécies de térmitas foram encontradas e quantificadas nos três remanescentes. A biomassa variou de 10,09 a $11,30 \mathrm{~g}$ (peso fresco) $/ \mathrm{m}^{2}$ e a abundância variou de 4911 a 5663 indivíduos $/ \mathrm{m}^{2}$. A subfamília Nasutitermitinae foi a dominante em número de espécies, biomassa e abundância. O grupo dos consumidores de húmus foi o mais abundante nos três sítios, enquanto os consumidores de madeira apresentaram a maior biomassa pelo menos na PEDI e na APMB. Entre os microhabitats quantificados, os térmitas foram encontrados principalmente no solo, estando fortemente concentrados entre 0 e $20 \mathrm{~cm}$ de profundidade. Duas espécies destacaram-se tanto pela biomassa como pela abundância: Embiratermes parvirostris Constantino, no solo, e Nasutitermes corniger (Motschulsky), nos troncos em decomposição e em ninhos. As estimativas de biomassa e de abundância sugerem que os térmitas desempenham um importante papel como mediadores do processo de decomposição da necromassa vegetal nos remanescentes de Mata Atlântica do Nordeste Brasileiro.

PALAVRAS-CHAVE. Distribuição vertical; Isoptera; levantamento quantitativo; ninho; região Neotropical.

Termites are among the invertebrates having the largest biomass and abundance in tropical humid forests (Wood \& Sands 1978; Martius 1994a; Bignell \& Eggleton 2000). Termites are distributed in a great variety of microhabitats in these ecosystems, such as in the soil, on decomposing trunks, on leaf litter, in abandoned or active nests, and inside living trees or in their canopy. Due to this diversity of life styles, the populations of these insects are relatively difficult to evaluate quantitatively (Eggleton \& Bignell 1995).

The biomass and abundance of termites in tropical forests can exceed $100 \mathrm{~g} / \mathrm{m}^{2}$ and 10,000 individuals $/ \mathrm{m}^{2}$, respectively (Eggleton et al. 1996). Termites can correspond to up to $95 \%$ of all of the below ground level insect biomass (Watt et al. 1997) and up to $82 \%$ of the biomass of invertebrates in decomposing trunks (Bandeira \& Torres 1985).

The precise determination of the biomass of an animal population allows a more realistically evaluate of their relative importance in the ecosystem than any other single quantitative indicator (Martius 1998). Although quantification of biomass and abundance are two of the most important parameters used to evaluate the functional role of a species or an assemblage of termites in a given ecosystem, quantitative studies of the termite fauna have been relatively scarce in humid tropical forests (see Matsumoto 1976; Abe \& Matsumoto 1979; Bandeira 1979; Wood et al. 1982; Collins 1984; Bandeira \& Torres 1985; Martius 1994a; Eggleton et al. 1996; Bandeira \& Vasconcellos 2002).

The great majority of the surveys of termite biomass and abundance in the Neotropical region have been undertaken in the Brazilian Amazon (Bandeira \& Torres 1985; Martius \& Ribeiro 1996; Bandeira \& Harada 1998; Martius 1998), while only three quantitative surveys have been undertaken 
in areas within the Atlantic Forest complex (Silva \& Bandeira 1999; Silva 2000; Bandeira \& Vasconcellos 2002). The present study undertook a quantitative survey of the biomass and abundance of termites in nests, in the soil (down to 30 $\mathrm{cm}$ ), and on trunks and leaf litter in three remnant areas of Atlantic Forest in northeastern Brazil located north of the São Francisco River.

\section{MATERIAL AND METHODS}

Three remnant areas of Atlantic Forest were examined: the Reserva Biológica de Pedra Talhada - RBPT; the Parque Estadual Dois Irmãos - PEDI; and the Área de Proteção Ambiental Mata do Buraquinho - APMB. The RBPT $\left(9^{\circ} 15^{\prime}\right.$ $\mathrm{S} ; 36^{\circ} 25^{\prime} \mathrm{W}$ ) is located in the municipality of Quebrangulo, Alagoas State, Brazil, and occupies and area of 4,636 ha, with altitudes varying from 450 to $883 \mathrm{~m}$ a.s.l. The topsoil is a sandy red-yellow podzol. The average annual temperatures and humidity are $23{ }^{\circ} \mathrm{C}$ and $84 \%$, respectively. Annual rainfall is approximately $1,267 \mathrm{~mm}$. The PEDI $\left(8^{\circ} 02^{\prime} \mathrm{S} ; 34^{\circ} 54^{\prime} \mathrm{W}\right)$ is located in the municipality of Recife, Pernambuco State, and occupies and area of 387 ha, with altitudes varying from 30 to $90 \mathrm{~m}$ a.s.l. The topsoil is a sandy red-yellow podzol. The average annual temperatures and humidity are $26^{\circ} \mathrm{C}$ and 82 $\%$, respectively. The annual rainfall is approximately 1,760 $\mathrm{mm}$. The APMB $\left(07^{\circ} 07^{\prime} \mathrm{S} ; 34^{\circ} 51^{\prime} \mathrm{W}\right)$ is situated in the urban perimeter of the municipality of João Pessoa, Paraíba State. It occupies an area of 515 ha of a slightly rolling landscape, with altitudes varying from 35 to $85 \mathrm{~m}$. The topsoil is a sandy red-yellow podzol. The average annual temperatures and humidity are $27^{\circ} \mathrm{C}$ and $80 \%$, respectively, and the annual rainfall is 1,482 mm (Governo do Estado da Paraíba 1985).

\section{Quantitative surveys}

Estimates of termite biomass and abundance were made during the months of June and July (rainy season) and during November and December (dry season), 2000, between 07:00 and 15:00. Collections were made in four microhabitats: leaf litter, nests (arboreal and epigeal), on the soil (at depths up to $30 \mathrm{~cm}$ ), and in tree trunks.

\section{Leaf litter}

In each study area, twenty $50 \times 50 \mathrm{~cm}$ plots were laid out in each season (a total of 40) and all of the leaves and branches within the plots were harvested and transported to the laboratory where the termites were collected manually and later counted and weighed. Their biomass (for this microhabitat as well as for the others) was calculated after estimating the average number of individuals (fresh weight) per gram of each of the species encountered in the study plots. This was accomplished by weighing five sub-samples of live termite soldiers and workers on an analytical balance, and extrapolating the values to $1 \mathrm{~g}$. In some cases, due to difficulties involved in acquiring sufficient individuals for weighing, the weight of the termites of one species was extrapolated to others of the same genus.

\section{Nests}

In general, four $100 \times 10 \mathrm{~m}$ plots were laid out in each area, and all of the nests encountered within their borders, with up to $5 \mathrm{~m}$ above the ground, were counted. For each species, the populations of at most four nests (the first four encountered) were quantified. These nests were removed from their substrates, measured to estimate their volume, and then opened on top of a plastic sheet to harvest and weigh three nest fragments (from which the termites would later be extracted). These fragments represented from 2 to $15 \%$ of the total weight of the nest and were removed (whenever possible) in the form of layers from the basal, medium, and upper layers of the nests. When a given nest was very large, this was fragmented in the field (in the most convenient manner) in order to remove the sub-samples. Based on the quantitative averages of these fragments, the total population of the nest was estimated. By determining the average populations in the nests, and knowing the densities of these constructions within the plots, I was able to estimate the abundance and biomass of the termites in these microhabitats.

\section{Soil}

The method utilized to capture termites in the soil was based on a protocol proposed by the "Tropical Soil Biology and Fertility Programme (TSBF)" (Anderson \& Ingram 1987) and adapted by Bandeira \& Vasconcellos (2002). Ten 20 X 20 X $30 \mathrm{~cm}$ monoliths $\left(12 \mathrm{dm}^{3}\right)$ were made in each area, five in rainy season and five in dry season. Each monolith was divided into three $20 \times 20 \times 10 \mathrm{~cm}$ layers and all of the termites within them were collected manually and later counted and weighed.

\section{Wood}

During each season, five 6 X $5 \mathrm{~m}$ plots $\left(30 \mathrm{~m}^{2}\right.$ each $)$ were laid out in each of the study areas. All of the decomposing pieces of wood in these plots with diameters greater than 1 $\mathrm{cm}$ were collected and weighed using a mechanical scale. A $5 \mathrm{KG}$ sample of the wood gathered in each plot was then removed (using a chain-saw if necessary) and all of the termites present in this material were collected manually and later counted and weighed. The abundance of the termites in these $5 \mathrm{KG}$ sample of wood was extrapolated to the total weight of all of the wood encountered in the plot.

Although collections were made during the dry and rainy seasons, the strong negative binominal distribution of the data of abundance and biomass as well as the high number of samples in which no individuals were found made comparisons between the seasons impossible. Even after $\log (\mathrm{x}+1)$ transformation, it was not possible to employ parametric or non-parametric tests to the data. As such, the data related to abundance and biomass was expressed as arithmetic averages after combining the values encountered in both seasons. In studies concerning termite ecology, arithmetic averages are commonly used to express quantitative values for the populations (Wood \& Sands 1978; Eggleton et al. 1996; Bandeira \& Harada 1998; Inoue et al. 2001, Bandeira \& Vasconcellos 2002). 


\section{RESULTS}

Thirty seven species of termites belonging to 23 genera and three families were encountered in the three remnant areas of Atlantic Forest (Table I). The greatest biomass of termites was registered for the RBPT site, while the greatest species richness was observed in the APMB site. The family Kalotermitidae represented from 0 to $0.59 \%$, the Rhinotermitidae from 0 to $4.66 \%$, and the Termitidae from 94.75 to almost $100 \%$ of the total estimated biomass of the three remnant forest areas. Likewise, the family Kalotermitidae represented from 0.01 to $0.04 \%$, the Rhinotermitidae from 0.02 to $4.73 \%$, and the Termitidae from 95.25 to $99.97 \%$ of the total estimated abundance in these same areas. The subfamily Nasutitermitinae was dominant in terms of biomass, abundance, and species richness, principally in the RBPT.

The soil-feeders demonstrated the greatest abundance values in all three areas examined. In terms of biomass, the soil-feeders were predominant in the RBPT, while the woodfeeders were predominant in the APMB and PHDI (Fig. 1).

Fifteen termite species were encountered in the soil, with nine being exclusive to that microhabitat, and the soil microhabitat had the largest biomass and abundance of termites (Table II). The species Embiratermes parvirostris Constantino was predominant in the ground in all three areas and was the main species responsible for the overall elevated biomass and abundance of termites in this microhabitat. Twenty six species of termites were encountered associated with wood and demonstrated some degree of association or dependence in relation to wood, but only ten of these species were encountered exclusively in that microhabitat. Among the wood-feeders, Nasutitermes corniger (Motschulsky) was predominant. Even soil-feeders such as Anoplotermes banksi Emerson and Labiotermes labralis (Holmgren) were encountered in tunnels or inside pieces of wood. Six species were encountered on leaf litter, but only Velocitermes sp. was found exclusively in this microhabitat and was predominant there in terms of biomass and abundance.

Ten species of termites constructed conspicuous nests in the three remnant forest areas. The density of conspicuous nests in the study areas varied from 24.0 to 92.8 nests/ha. In general, Armitermes holmgreni Snyder, Microcerotermes exiguus (Hagen), N. corniger, and L. labralis were the principal nest constructing species (Table III). The populations of six species from nests were quantified in RBPT, seven in PHDI and eight in APMB (Table 3). As nests of Nasutitermes sp. were constructed more than $10 \mathrm{~m}$ above the ground and were generally attached to lianas, their population was not quantified - and only the density of their nests was estimated. The low density of nests encountered in RBPT was due to the absence in that plot of any species of Microcerotermes (notably M. exiguus, which was quite common in the other remnants). Nests of $N$. corniger were also scarce in this remnant site. On the other hand, nests of Embiratermes neotenicus (Holmgren) were observed to be exclusive to the RBPT site, with an average population of approximately 300,000 individuals/nest.

Approximately 80 to $100 \%$ of the species collected in the earth samples were encountered at depths up to $20 \mathrm{~cm}$. All of the species in the RBPT were encountered up to the $20 \mathrm{~cm}$ depth - but only Aparatermes sp. in the PHDI and Anoplotermes sp. b and Anoplotermes sp. c in APMB were encountered between 20-30 cm depth. In the RBPT site, the soil termites were concentrated at a depth of $10-20 \mathrm{~cm}$, but in PEDI and APMB most individuals were found $0-10 \mathrm{~cm}$ deep. Approximately 83.0 to $90.2 \%$ of the abundance and biomass of ground termites was encountered at depths of $0-20 \mathrm{~cm}$ in all three areas.

\section{DISCUSSION}

The estimates of biomass and abundance of termites in the three remnant areas of humid tropical Atlantic Forest in northeastern Brazil were found to be similar to the amplitudes previously recorded for other tropical forests around the world (review in Bignell \& Eggleton 2000). The three studied areas (together with the Brejo dos Cavalos, site described by Bandeira \& Vasconcellos 2002) demonstrated the greatest recorded abundance values for termites in the Neotropical region (Bandeira \& Torres 1985; Martius 1994a; Bandeira \&
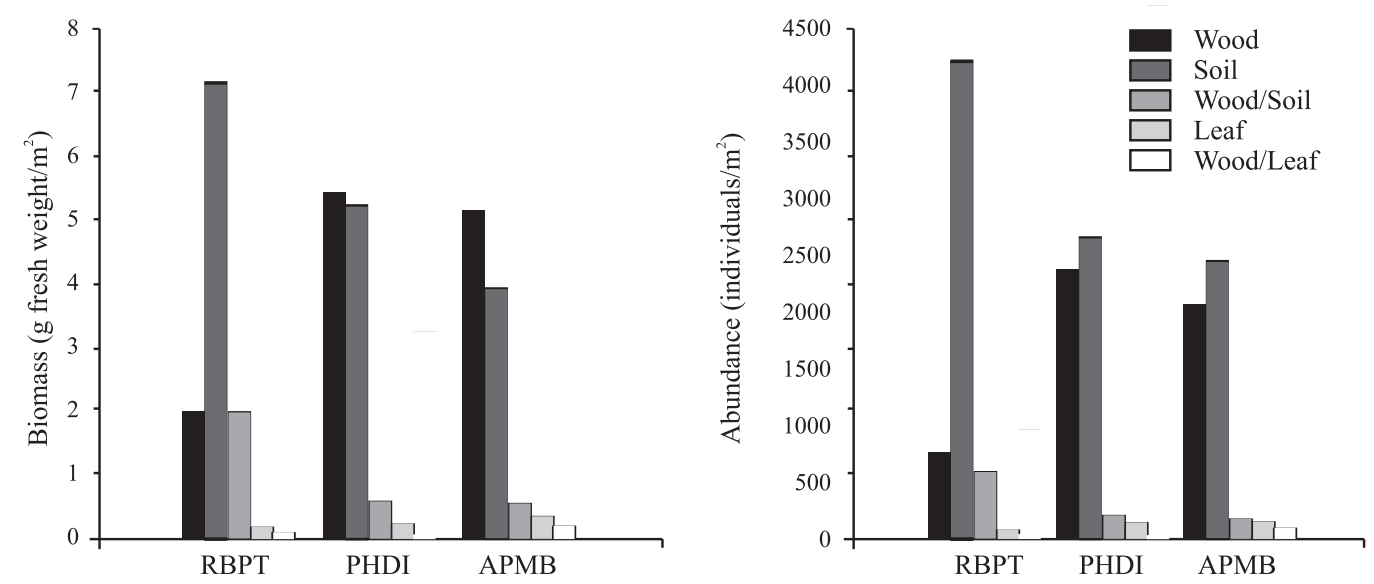

Fig. 1. Termite biomass and abundance per feeding group in three remnant areas of Atlantic Forest in northeastern Brazil. RBPT $=$ Reserva Biológica de Pedra Talhada; PEDI = Parque Estadual Dois Irmãos; APMB = Área de Proteção Ambiental Mata do Buraquinho. 
Table I. Biomass ( $\mathrm{g}$ fresh weight $/ \mathrm{m}^{2}$ ) and abundance (individuals $/ \mathrm{m}^{2}$ ) of termites in three remnant areas of Atlantic Forest in northeastern Brazil: RBPT $=$ Reserva Biológica de Pedra Talhada; PEDI = Parque Estadual Dois Irmãos; APMB = Área de Proteção Ambiental Mata do Buraquinho.

\begin{tabular}{|c|c|c|c|c|c|c|c|c|}
\hline \multirow{2}{*}{ TAXA } & \multicolumn{2}{|c|}{ RBPT } & \multicolumn{2}{|c|}{ PEDI } & \multicolumn{2}{|c|}{ APMB } & \multirow{2}{*}{$\begin{array}{c}\text { Nest sites/ } \\
\text { Feeding groups }\end{array}$} & \multirow{2}{*}{$\begin{array}{l}\text { Micro- } \\
\text { habitats }\end{array}$} \\
\hline & Biom & Abun. & Biom. & Abun. & Biom. & Abun. & & \\
\hline \multicolumn{9}{|l|}{ KALOTERMITIDAE } \\
\hline Calcaritermes rioensis Krishna & & & & & 0.06 & 1.75 & $\mathrm{~W} / \mathrm{W}$ & Wo \\
\hline Glyptotermes sp. & $0^{*}$ & 0.6 & & & & & $\mathrm{~W} / \mathrm{W}$ & Wo \\
\hline Rugitermes sp. & & & $0 *$ & 0.4 & & & $\mathrm{~W} / \mathrm{W}$ & Wo \\
\hline \multicolumn{9}{|l|}{ RHINOTERMITIDAE } \\
\hline Coptotermes testaceus (Linnaeus) & & & & & 0.14 & 45.75 & $\mathrm{~S} / \mathrm{W}$ & Wo/So \\
\hline Heterotermes longiceps (Snyder) & & & 0.52 & 254.95 & 0.33 & 157.60 & $\mathrm{~S} / \mathrm{W}$ & Wo/So \\
\hline Rhinotermes hispidus Emerson & $0^{*}$ & 1.30 & & & & & $\mathrm{~S} / \mathrm{W}$ & Wo \\
\hline \multicolumn{9}{|l|}{ TERMITIDAE: Apicotemitinae } \\
\hline Aparatermes sp. & 0.28 & 112.65 & 0.08 & 32.85 & & & $\mathrm{~S} / \mathrm{S}$ & So \\
\hline Anoplotermes banksi Emerson & 0.04 & 34.25 & 0.05 & 40.51 & 0.27 & 216.65 & $\mathrm{~A} / \mathrm{S}$ & $\mathrm{Wo} / \mathrm{So} / \mathrm{Ne}$ \\
\hline Anoplotermes sp. a & 0.97 & 426.10 & 0.91 & 397.55 & & & $\mathrm{~S} ? / \mathrm{S}$ & So \\
\hline Anoplotermes sp. b & & & & & 0.38 & 188.70 & $\mathrm{~S} ? / \mathrm{S}$ & So \\
\hline Anoplotermes sp. c & & & & & 0.43 & 652.25 & $\mathrm{~S} ? / \mathrm{S}$ & So \\
\hline Ruptitermes sp. & $0^{*}$ & 11.55 & 0.11 & 44.15 & 0.18 & 75.75 & $\mathrm{~S} / \mathrm{L}$ & $\mathrm{Ll} / \mathrm{S}$ \\
\hline \multicolumn{9}{|l|}{ TERMITIDAE: Nasutitermitinae } \\
\hline Armitermes holmgreni Snyder & 0.54 & 196.89 & 0.34 & 125.85 & 0.18 & 59.9 & $\mathrm{~A} / \mathrm{W}-\mathrm{S}$ & $\mathrm{Wo} / \mathrm{Ne}$ \\
\hline Diversitermes sp. & 0.08 & 34.85 & 0.06 & 25.20 & 0.21 & 87.10 & $\mathrm{Ll} / \mathrm{W}-\mathrm{L}$ & Wo/Ll \\
\hline Embiratermes neotenicus (Holmgren) & 0.97 & 248.15 & & & 0.18 & 29.60 & E/W-S & $\mathrm{Wo} / \mathrm{Ne} / \mathrm{So}$ \\
\hline Embiratermes parvirostris Constantino & 5.46 & 3552.01 & 2.67 & 1740.75 & 1.82 & 1184.40 & $\mathrm{~S} / \mathrm{W}-\mathrm{S}$ & So \\
\hline Labiotermes labralis (Holmgren) & 0.39 & 80.41 & 0.67 & 135.9 & 0.98 & 199.82 & $\mathrm{~A} / \mathrm{S}$ & $\mathrm{Ne} / \mathrm{So} / \mathrm{Wo}_{0}$ \\
\hline Nasutitermes callimorphus Mathews & & & 0.06 & 30.5 & 0.19 & 96.30 & $\mathrm{~L} 1 ? / \mathrm{W}$ & Wo/Ll \\
\hline Nasutitermes corniger (Motschulsky) & 1.08 & 413.65 & 1.18 & 462.15 & 1.50 & 587.45 & $\mathrm{~A} / \mathrm{W}$ & $\mathrm{Wo} / \mathrm{Ne}$ \\
\hline Nasutitermes ephratae (Holmgren) & 0.32 & 124.85 & 0.80 & 316.15 & 0.38 & 151.55 & $\mathrm{~A} / \mathrm{W}$ & $\mathrm{Wo} / \mathrm{Ne}$ \\
\hline Nasutitermes gaigei Emerson & & & 0.42 & 205.4 & 0.35 & 170.60 & $\mathrm{~W} ? / \mathrm{W}$ & Wo \\
\hline Nasutitermes jaraguae (Holmgren) & 0.46 & 181.35 & 0.08 & 30.15 & 0.29 & 119.85 & $\mathrm{~W} ? / \mathrm{W}$ & Wo \\
\hline Nasutitermes macrocephalus (Silvestri) & & & 0.14 & 40.8 & 0.63 & 173.25 & $\mathrm{~A} / \mathrm{W}$ & $\mathrm{Wo} / \mathrm{Ne}$ \\
\hline Nasutitermes rotundatus (Holmgren) & 0.08 & 20.65 & & & & & $\mathrm{~W} ? / \mathrm{W}$ & Wo \\
\hline Nasutitermes sp. & & & 0.07 & 28.5 & 0.13 & 52.40 & $\mathrm{~A} / \mathrm{W}$ & $\mathrm{Wo} / \mathrm{Ne}$ \\
\hline Subulitermes microsoma (Silvestri) & & & $0^{*}$ & 4.10 & & & $\mathrm{~W} ? / \mathrm{S}$ & Wo \\
\hline Velocitermes sp. & 0.15 & 65.40 & 0.12 & 93.2 & 0.13 & 75.00 & $\mathrm{Ll} / \mathrm{W}-\mathrm{L}$ & Fol \\
\hline \multicolumn{9}{|l|}{ TERMITIDAE: Termitinae } \\
\hline Amitermes amifer Silvestri & & & 1.27 & 591.70 & 0.31 & 168.55 & $\mathrm{~W} / \mathrm{W}$ & Wo/So \\
\hline Cylindrotermes sapiranga Rocha \& Cancello & & & & & 0.14 & 90.60 & $\mathrm{~W} / \mathrm{W}$ & Wo \\
\hline Dentispicotermes cf. conjunctus Araujo & & & 0.83 & 292.61 & 0.02 & 7.85 & $\mathrm{~S} / \mathrm{S}$ & So \\
\hline Microcerotermes exiguus (Hagen) & & & 0.82 & 419.20 & 0.53 & 173.60 & $\mathrm{~A} / \mathrm{W}$ & $\mathrm{Wo} / \mathrm{Ne} / \mathrm{Ll}$ \\
\hline Microcerotermes strunckii (Sorensen) & 0.02 & 10.11 & & & 0.16 & 70.45 & $\mathrm{~A} / \mathrm{W}$ & $\mathrm{Wo} / \mathrm{Ne}$ \\
\hline Neocapritermes guyana Krishna \& Araujo & 0.46 & 147.60 & & & & & $\mathrm{~S} / \mathrm{W}-\mathrm{S}$ & So \\
\hline Neocapritermes opacus (Hagen) & & & 0.015 & 2.61 & $0^{*}$ & 1.65 & $\mathrm{~S} / \mathrm{W}-\mathrm{S}$ & Wo/So \\
\hline Neocapritermes talpoides Krishna \& Araujo & & & 0.215 & 65.45 & 0.13 & 45.05 & $\mathrm{~S} / \mathrm{W}-\mathrm{S}$ & So \\
\hline Orthognathotermes sp. & & & & & $0^{*}$ & 1.05 & $\mathrm{~S} / \mathrm{S}$ & So \\
\hline Termes medioculatus Emerson & $0^{*}$ & 0.17 & $0^{*}$ & 3.10 & 0.04 & 26.45 & $\mathrm{~W} ? / \mathrm{W}-\mathrm{S}$ & Wo \\
\hline Total & 11.30 & 5662.54 & 11.43 & 5383.73 & 10.09 & 4910.92 & & \\
\hline Number of species & & 19 & & 25 & & 29 & & \\
\hline
\end{tabular}

* Biomass values less than $0.01 \mathrm{gm}$.

Nest sites: $\mathrm{W}=$ nest inside wood; $\mathrm{L}=$ nest under litter; $\mathrm{S}=$ subterranean; $\mathrm{A}=$ arboreal; $\mathrm{E}=$ epigeal; $\mathrm{I}=$ inhabiting nests of other termites.

Feeding groups: $\mathrm{W}=$ wood-feeders; $\mathrm{S}=$ soil-feeders; $\mathrm{L}=$ leaf-feeders; $\mathrm{W}-\mathrm{S}=$ wood-soil interface feeders; $\mathrm{W}-\mathrm{L}=$ wood-leaf interface feeders .

Microhabitats: $\mathrm{Wo}=$ wood; $\mathrm{Ne}=$ nest; $\mathrm{Ll}=$ leaf litter; $\mathrm{So}=$ Soil.

Harada 1998; Silva \& Bandeira 1999; Silva 2000). However, the largest estimated values of biomass were reported for a terra firme forest in the Central Amazon, with 14 to $17 \mathrm{~g}$ (fresh weight) $/ \mathrm{m}^{2}$, due principally to the occurrence of large leaf-feeders termites such as Syntermes molestus (Burmeister) and Syntermes spinosus (Latreille), considered to be among the largest Neotropical termites (Martius 1998). Not a single species of this genus was encountered consuming leaves in the interior of the Atlantic Forest Complex of northeastern Brazil. The species Syntermes nanus Constantino occurred in environments near the forest areas (generally in open areas where the primary vegetation had been totally removed) and were easily seen foraging between sunset and sunrise in isolated fragments of Cerrado vegetation near the coast or in sugarcane plantations (Sena et al. 2003; Miranda et al. 2004). 
Table II. Biomass ( $\mathrm{g}$ fresh weight $/ \mathrm{m}^{2}$ ) and abundance (individuals $/ \mathrm{m}^{2}$ ) per microhabitats in three remnant areas of Atlantic Forest in northeastern Brazil. RBPT $=$ Reserva Biológica de Pedra Talhada; PEDI = Parque Estadual Dois Irmãos; APMB = Área de Proteção Ambiental Mata do Buraquinho.

\begin{tabular}{|c|c|c|c|c|c|c|c|c|c|c|c|c|}
\hline & \multicolumn{4}{|c|}{ RBPT } & \multicolumn{4}{|c|}{ PHDI } & \multicolumn{4}{|c|}{ APMB } \\
\hline & Biom & $\%$ & Abund & $\%$ & Biom & $\%$ & Abun & $\%$ & Biom & $\%$ & Abund & $\%$ \\
\hline Leaf litter & 0.22 & 1.95 & 118.39 & 2.09 & 0.79 & 6.91 & 293.03 & 5.44 & 0.89 & 8.82 & 341.15 & 6.95 \\
\hline Wood & 1.30 & 11.50 & 334.72 & 5.91 & 1.70 & 14.87 & 622.9 & 11.57 & 1.87 & 18.53 & 818.32 & 16.66 \\
\hline Nest & 2.13 & 18.85 & 877.89 & 15.50 & 3.10 & 27.12 & 1130.9 & 21.01 & 3.36 & 33.30 & 1551.15 & 31.59 \\
\hline Soil & 7.65 & 67.70 & 4331.54 & 76.49 & 5.84 & 51.09 & 3336.9 & 61.98 & 3.97 & 39.35 & 2200.3 & 44.80 \\
\hline Total & 11.30 & 100 & 5662.54 & 100 & 11.43 & 100 & 5383.73 & 100 & 10.09 & 100 & 4910.92 & 100 \\
\hline
\end{tabular}

The maximum values of biomass and abundance for termites in a primary tropical forest in the Mbalmayo Forest Reserve in Africa were estimated to be $123.2 \mathrm{~g}$ (fresh weight) $/ \mathrm{m}^{2}$ and 6957 individuals $/ \mathrm{m}^{2}$ respectively (Eggleton et al. 1996). These values correspond to approximately $69,570,000$ individuals/ha and a biomass of 1.2 metric tons (fresh weight)/ha.

There is still little information available about termite biomass and abundance in the forests of the Atlantic Forest Complex of South America. Silva \& Bandeira (1999) studied the variation in abundance of soil termites during a twelve month period in the APMB site and estimated that there were approximately 1,573 and 2,151 individuals $/ \mathrm{m}^{2}$ during the dry and rainy seasons, respectively. In a quantitative survey of the termite fauna in an anthropogenic disturbance gradient (a near-primary forest area / secondary forest / banana plantation) in a highland forest area in northeastern Brazil, Bandeira \& Vasconcellos (2002) reported that the diversity, abundance, and biomass of termites diminished along the gradient from primary forest to the banana plantation. In these two areas the biomass varied from 2.39 (445.5 individuals) $\mathrm{g} / \mathrm{m}^{2}$ to 13.18 (4845.5 individuals) $\mathrm{g} / \mathrm{m}^{2}$, respectively.

In the present study, the soil microhabitat presented the largest termite biomass ( 39.35 to $67.70 \%$ of the total) and abundance ( 44.80 to $76.49 \%$ of the total). However, a majority of the species were encountered associated with wood. The high species richness in a given microhabitat, such as tree trunks, is usually associated with high abundance (Martius

Table III. Population of nests, biomass ( $\mathrm{g}$ fresh weight $/ \mathrm{m}^{2}$ ) and abundance (individuals $/ \mathrm{m}^{2}$ ) of termites constructing conspicuous nests in three remnant areas of Atlantic Forest in northeastern Brazil. RBPT $=$ Reserva Biológica de Pedra Talhada; PEDI = Parque Estadual Dois Irmãos; APMB = Área de Proteção Ambiental Mata do Buraquinho.

\begin{tabular}{|c|c|c|c|c|c|c|c|}
\hline Areas/Species & $\begin{array}{c}\text { Nests } \\
\text { quantified }\end{array}$ & Nests/ha & Amplitude & $\begin{array}{c}\text { Average } \\
\text { Population }\end{array}$ & Amplitude & $\begin{array}{c}\text { Abundance } \\
\left(\mathrm{m}^{2}\right)\end{array}$ & $\begin{array}{c}\text { Biomass } \\
\left(\mathrm{m}^{2}\right)\end{array}$ \\
\hline \multicolumn{8}{|l|}{ RBPT } \\
\hline Anoplotermes banksi & 4 & 2 & $0-10$ & 27330 & $8297-58391$ & 5.46 & 0.007 \\
\hline Armitermes holmgreni & 3 & 5 & $1-8$ & 83431 & $35410-102301$ & 41.7 & 0.11 \\
\hline Embiratermes neotenicus & 4 & 5 & $3-11$ & 298347 & $57388-645442$ & 148.17 & 0.58 \\
\hline Labiotermes labralis & 3 & 4 & $2-8$ & 69538 & $53535-99878$ & 27.8 & 0.13 \\
\hline Nasutitermes corniger & 3 & 4 & $1-12$ & 175522 & $27781-398150$ & 70.2 & 0.18 \\
\hline Nasutitermes ephratae & 4 & 4 & $2-9$ & 187531 & $61397-462301$ & 75.0 & 0.21 \\
\hline Total & 21 & 24 & $9-58$ & 841699 & $243808-1766463$ & 368.33 & 1.28 \\
\hline \multicolumn{8}{|l|}{ PHDI } \\
\hline Anoplotermes banksi & 6 & 10 & $5-16$ & 32510 & $3003-41230$ & 32.51 & 0.04 \\
\hline Armitermes holmgreni & 4 & 7 & $4-11$ & 55781 & $47889-93447$ & 39 & 0.10 \\
\hline Labiotermes labralis & 4 & 9 & $5-13$ & 85496 & $36385-120236$ & 76.9 & 0.38 \\
\hline Microcerotermes exiguus & 5 & 24 & $15-33$ & 37199 & $3538-63450$ & 89.3 & 0.17 \\
\hline Nasutitermes corniger & 8 & 12 & $8-31$ & 294030 & $43002-682500$ & 352.8 & 0.93 \\
\hline Nasutitermes ephratae & 8 & 6 & $4-11$ & 288410 & $48670-702550$ & 173.0 & 0.49 \\
\hline Nasutitermes macrocephalus & 3 & 0.6 & $0-3$ & 680101 & $175440-803600$ & 40.8 & 0.14 \\
\hline Nasutitermes sp. & 0 & 0.4 & $0-2$ & - & - & - & - \\
\hline Total & 38 & 69 & $41-120$ & 1473527 & $357927-2507013$ & 804.31 & 2.25 \\
\hline \multicolumn{8}{|l|}{ APMB } \\
\hline Anoplotermes banksi & 6 & 8 & $3-14$ & 37112 & $4120-48530$ & 29.68 & 0.037 \\
\hline Armitermes holmgreni & 6 & 11 & $5-15$ & 41091 & $27596-96378$ & 45.2 & 0.10 \\
\hline Labiotermes labralis & 6 & 13 & $5-18$ & 98839 & $39358-162535$ & 128.4 & 0.63 \\
\hline Microcerotermes exiguus & 6 & 29 & $13-38$ & 47389 & $6788-98531$ & 137.4 & 0.27 \\
\hline Microceroterems strunckii & 2 & 0.5 & $0-2$ & 28784 & $15236-42333$ & 2.8 & 0.006 \\
\hline Nasutitermes corniger & 8 & 15 & $10-26$ & 242785 & $52232-951102$ & 364.17 & 0.96 \\
\hline Nasutitermes ephratae & 8 & 4 & $2-8$ & 201244 & $59300-610800$ & 80.5 & 0.23 \\
\hline Nasutitermes macrocephalus & 4 & 0.3 & $0-2$ & 514760 & $200510-1100510$ & 15.44 & 0.056 \\
\hline Nasutitermes sp. & 0 & 0.7 & $0-4$ & - & - & - & - \\
\hline Total & 46 & 81.5 & $38-127$ & 1246551 & $405140-3170719$ & 841.59 & 2,419 \\
\hline
\end{tabular}


Table IV. Available data on termite nest density and their populations in Neotropical humid and semideciduous forests.

\begin{tabular}{|c|c|c|c|c|c|c|c|c|}
\hline Species & $\begin{array}{l}\text { Nests } \\
\text { /ha }\end{array}$ & $\begin{array}{l}\text { Ampli- } \\
\text { tude }\end{array}$ & $\begin{array}{l}\text { Average } \\
\text { Population }\end{array}$ & $\begin{array}{l}\text { Ampli- } \\
\text { tude }\end{array}$ & $\begin{array}{l}\text { Abun. } \\
\text { (ind. } / \mathrm{m}^{2} \text { ) }\end{array}$ & $\begin{array}{l}\text { Biom. } \\
\left(\mathrm{gm} / \mathrm{m}^{2}\right)\end{array}$ & Locality & Authors \\
\hline Anoplotermes banksi & - & - & 55864 & - & - & - & Eastern Amazon & Bandeira \& Torres (1985) \\
\hline Anoplotermes banksi & - & $12-18$ & 18440 & $\begin{array}{l}2593- \\
39256\end{array}$ & $25-38$ & $\begin{array}{c}0.045- \\
0.069\end{array}$ & Central Amazon & Martius \& Ribero (1996) \\
\hline Armitermes holmgreni & - & $13-14$ & - & - & - & - & $\begin{array}{c}\text { Semideciduous Atlantic } \\
\text { Forests }\end{array}$ & Vasconcellos et al. (2008) \\
\hline Labiotermes labralis & 10 & - & 135000 & - & - & - & Central Amazon & Martius \& Ribeiro (1996) \\
\hline Labiotermes labralis & - & $4-8$ & - & - & - & - & $\begin{array}{c}\text { Semideciduous Atlantic } \\
\text { Forests }\end{array}$ & Vasconcellos et al. (2008) \\
\hline Microcerotermes exiguus & - & $26-54$ & - & - & - & - & $\begin{array}{c}\text { Semideciduous Atlantic } \\
\text { Forests }\end{array}$ & Vasconcellos et al. (2008) \\
\hline Microcerotermes strunckii & - & $0-3$ & - & - & - & - & $\begin{array}{c}\text { Semideciduous Atlantic } \\
\text { Forests }\end{array}$ & Vasconcellos et al. (2008) \\
\hline Nasutitermes corniger & - & - & 202097 & $\begin{array}{l}40092- \\
435890\end{array}$ & - & - & Central America & Thorne (1982) \\
\hline Nasutitermes corniger & - & $\begin{array}{l}31.6- \\
47.1\end{array}$ & - & - & - & - & $\begin{array}{l}\text { Central Amazon: } \\
\text { seasonally flooded }\end{array}$ & Martius (1994b). \\
\hline Nasutitermes corniger & - & $20-23$ & - & - & - & - & $\begin{array}{c}\text { Semideciduous Atlantic } \\
\text { Forests }\end{array}$ & Vasconcellos et al. (2008) \\
\hline Nasutitermes costalis & - & - & - & - & $87-104$ & 0.3 & Central America & Wiegert (1970) \\
\hline Nasutitermes ephratae & - & $0-2.7$ & - & - & - & - & $\begin{array}{l}\text { Central Amazon: } \\
\text { seasonally flooded }\end{array}$ & Martius (1994b) \\
\hline Nasutitermes ephratae & 25 & - & - & - & - & - & Highland humid Forest & Bandeira et al. (2003) \\
\hline Nasutitermes ephratae & - & $7-10$ & - & - & - & - & $\begin{array}{c}\text { Semideciduous Atlantic } \\
\text { Forests }\end{array}$ & Vasconcellos et al. (2008) \\
\hline Nasutitermes macrocephalus & - & $0-4$ & 1375000 & $\begin{array}{l}150000- \\
1500000\end{array}$ & 544 & 1.8 & $\begin{array}{l}\text { Central Amazon: } \\
\text { seasonally flooded }\end{array}$ & Martius (1994b) \\
\hline Nasutitermes macrocephalus & - & $0-2$ & - & - & - & - & $\begin{array}{c}\text { Semideciduous Atlantic } \\
\text { Forests }\end{array}$ & Vasconcellos et al. (2008) \\
\hline Nasutitermes surinamensis & - & $1.7-3$ & - & - & - & - & $\begin{array}{l}\text { Central Amazon: } \\
\text { seasonally flooded }\end{array}$ & Martius (1994b) \\
\hline Nasutitermes tatarendae & - & $3.3-11$ & - & - & - & - & $\begin{array}{l}\text { Central Amazon: } \\
\text { seasonally flooded }\end{array}$ & Martius (1994b) \\
\hline Rotunditermes bragantinus & - & - & 77336 & - & - & - & Eastern Amazon & Bandeira \& Torres (1985) \\
\hline Syntermes molestus & 11.2 & - & 30000 & - & - & - & Central Amazon & Mill (1982) \\
\hline Syntermes spinosus & 3.8 & - & 37000 & - & - & - & Central Amazon & Mill (1982) \\
\hline
\end{tabular}

1994a). However, the results of the present study suggest that high species richness in a given microhabitat is not always directly associated with high biomass and abundance.

The RBPT area demonstrated the largest recorded biomass and abundance of soil termites. Large numbers of individuals were also reported in this same microhabitat in two other areas of the Atlantic Forest Complex at altitudes above 450 metros (Silva 2000; Bandeira \& Vasconcellos 2002). In addition to altitude, it is also likely that the amount of the clay in the soil influences termite abundances in these areas. According to Lee \& Wood (1971), termites are generally more abundant in areas with clay soils as opposed to sandy soils, as the stability of their tunnels and nests depends on the proportions of sand, silt, and clay.

The soil-feeders were dominants in terms of biomass and abundance in the soil microhabitat, with E. parvirostris being especially important. This same pattern was seen in the Brejo dos Cavalos (Bandeira \& Vasconcellos 2002) and Mata do Pau Ferro sites (Silva 2000). Additionally, Silva \& Bandeira (1999) reported E. parvirostris (which was referred to in their article as Embiratermes sp. b) to be the most abundant species among 25 found in the soil microhabitat in the APMB site.

The soil termite fauna was found to be concentrated in the first 0-20 cm of soil. Bandeira \& Vasconcellos (2002) likewise reported the greatest abundance of termites at depths up to $20 \mathrm{~cm}$, and found representatives of all of the termite species there, and noted that this depth would therefore be indicated for quantitative and qualitative surveys of the termite fauna - which would provide an increase in the number of sample replicates while maintaining the same collecting effort. Other studies undertaken in forests within the Atlantic Forest Complex have also reported a maximum of termite abundance and diversity in the first $20 \mathrm{~cm}$ of soil (Silva \& Bandeira 1999; Silva 2000).

Termite biomass and abundance were relatively high in tree trunks. Termites encountered in decomposing trunks and branches in the eastern Amazon were more abundant than any other group of animals in the primary forest, accounting for $82 \%$ of the biomass and $76 \%$ of the total abundance among more than 20 animal groups encountered in this microhabitat 
(Bandeira \& Torres 1985). These authors stressed that quantitative surveys that did not include decomposing trunks and branches would yield significant underestimations of termite populations in tropical ecosystems.

Very little information concerning termite populations in nests and their representativity in terms of relative biomass and abundance has been available for humid forests in the Neotropical region before the present study (Table IV). The high representativity of the species of Nasutitermes in terms of abundance and biomass in forests in the Neotropical region is related to the density of their nests.

Some species, such as E. neotenicus and A. banksi, have the ability to occupy various microhabitats. In the APMB site, only $13.7 \%$ of the individuals of $A$. banksi were present in the nests themselves, while the rest were in the ground (40.2\%) or in tree trunks in advanced states of decomposition (46.1\%). As such, estimates based only on nest populations could mask the true abundance of these species in the ecosystem.

The estimated biomass and abundance of termites in the remnant areas of Atlantic Forest in northeastern Brazil suggest that these insects are important elements within the dynamic ecological processes related to energy flow and nutrient cycling of the plant necromass.

Acknowledgements. The author would like to thank the Brazilian Ministry of Education (CAPES) for the doctoral grants; Dr. Adelmar Gomes Bandeira for orientating the execution of this study; Dr. Anita Studer for her support during the collections made at the Pedra Talhada Biological Reserve; Flávia Maria da Silva Moura for the critical reading of the manuscript; the Pernambuco State Government for its support during the collections made at the Horto Dois Irmãos State Park; and Moabe Pina da Silva and Waltécio de Oliveira Almeida for their aid with the field work.

\section{REFERENCES}

Abe, T. \& T. Matsumoto. 1979. Studies on the distribution and ecological role of termites in a lowland rain forest of West Malaysia. 3. Distribution and abundance of termites in Pasoh Forest Reserve. Japanese Journal of Ecology 29: 337-351.

Anderson, J. M. \& J. S. M. Ingram. 1987. Tropical soil biology and fertility methods handbook. Aberystwith, UNESCO/IUBS, $771 \mathrm{p}$.

Bandeira A. G. 1979. Ecologia de cupins (Insecta: Isoptera) da Amazônia Central: efeitos do desmatamento sobre as populações. Acta Amazonica 9: 481-499.

Bandeira, A. G. \& M. F. P. Torres. 1985. Abundância e distribuição de invertebrados do solo em ecossistemas da Amazônia Oriental. O papel ecológico dos cupins. Boletim do Museu Paraense Emílio Goeldi série Zoológica 2: 13-38.

Bandeira, A. G. \& A. Y. Harada. 1998. Densidade e distribuição vertical de macroinvertebrados em solos argilosos e arenosos na Amazônia Central. Acta Amazonica 28: 191-204.

Bandeira, A. G. \& A. Vasconcellos. 2002. A quantitative survey of termites in a gradient of disturbed highland forest in Northeastern Brazil (Isoptera). Sociobiology 39: 429-439.

Bandeira, A.G.; A. Vasconcellos; M. P. Silva \& R. Constantino. 2003. Effects of habitat disturbance on the termite fauna in a highland humid forest in the caatinga domain, Brazil. Sociobiology 42: 117-127.

Bignell, D. E. \& P. Eggleton. 2000. Termites in ecosystems, p. 363-387. In: T. Abe; M. Higashi \& D. E. Bignell (eds). Termites: Evolution, Sociality, Symbiosis, Ecology. Dordrecht, Kluwer Academic Publishers, 466 p.

Received 15/06/2009; accepted 15/07/2010

Editor: Márcio Roberto Pie
Collins, N. M. 1984. Termite populations and their role in litter removal in malaysian rain forest, p. 311-325. In: Sutton, S. L.; T. C. Whitmore \& C. Chadwick (eds). Tropical rain forest: ecology and management. Oxford, Blackwell Scientific Publications, 515 p.

Eggleton, P. \& D. E. Bignell. 1995. Monitoring the response of tropical insects to changes in the environmental: troubles with termites, p. 473-497. In: R. Harrington \& N. E. Stork (eds). Insects in a changing environment. London, Academic Press, $625 \mathrm{p}$.

Eggleton, P; D. E. Bignell; W. A. Sands; N. A. Mawdsley; J. H. Lawton; T. G. Wood \& N. C. Bignell. 1996. The diversity, abundance and biomass of termites under differing levels of disturbance in the Mbalmayo Forest Reserve, Southern Cameroon. Philosophical Transactions of the Royal Society of London, Series B 351: 51-68.

Governo do Estado da Paraíba. 1985. Atlas Geográfico do Estado da Paraíba. João Pessoa, Grafset, 100 p.

Inoue, T.; Y. Takematsu; F. Hyodo; A. Sugimoto; A. Yamada; C. Klagkaew; N. Kirtibutr \& T. Abe. 2001. The abundance and biomass of subterranean termites (Isoptera) in dry evergreen forest of Northeast Thailand. Sociobiology 37: 41-52.

Lee, K. E. \& T. G. Wood. 1971. Termites and soils. London, Academic Press, $251 \mathrm{p}$.

Martius, C. 1994a. Diversity and ecology of termites in Amazonian forest. Pedobiology 38: 407-428.

Martius, C. 1994b. Termite nests as structural elements of the Amazon floodplain forest. Andrias 13: 137-150.

Martius, C. \& J. D'arc. Ribeiro. 1996. Colony population and biomass in nests of the Amazonian forest termite Anoplotermes banksi Emerson (Isoptera, Termitidae). Studies on Neotropical Fauna and Environment 31: $1-5$.

Martius, C. 1998. Occurrence, body mass and biomass of Syntermes spp. (Isoptera, Termitidae) in Reserva Ducke, Central Amazonia. Acta Amazonica 28: 319-324.

Matsumoto, T. 1976. The role of termites in an equatorial rain forest ecosystem of West Malaysia: population density, biomass, carbon, nitrogen and calorific content and respiration rate. Oecologia 22: 153-178.

Mill, A. E. 1982. Populações de térmitas (Insecta: Isoptera) em quatro habitats no baixo rio Negro. Acta Amazonica 12: 53-60.

Miranda, C. S.; A. Vasconcellos \& A. G. Bandeira. 2004. Termites in Sugar Cane in Northeast Brazil: Ecological Aspects and Pest Status. Neotropical Entomology 33: 237-241.

Sena, J. M.; A. Vasconcellos; M. A. B. Gusmão \& A. G. Bandeira. 2003. Assemblage of termites in a fragment of Cerrado on the coast of Paraíba State, Northeast Brazil (Isoptera). Sociobiology 42: 753-760.

Silva, E.G. \& A. G. Bandeira. 1999. Abundância e distribuição de cupins (Insecta, Isoptera) em solo de Mata Atlântica, João Pessoa, Paraíba. Revista Nordestina de Biologia 13: 13-36.

Silva, M. P. 2000. Riqueza de espécies, abundância e hábito alimentar de cupins (Insecta, Isoptera) da Mata do Pau Ferro, Areia, Paraíba. M Sc. Dissertação, Universidade Federal da Paraíba, 45 p.

Thorne, B. 1982. Polygyny in termites: multiple primary queens in colonies of Nasutitermes corniger (Motschulsky) (Isoptera, Termitidae). Insectes Sociaux 29: 102-117.

Vasconcellos, A.; A. G. Bandeira; W. O. Almeida \& F. M. S. Moura. 2008. Térmitas construtores de ninhos conspícuos em duas Áreas de Mata Atlântica com diferentes níveis de perturbação antrópica. Neotropical Entomology 37: 15-19.

Watt, A. D.; N. E. Stork; C. McBeath \& G. L. Lawson. 1997. Impact of forest loss and regeneration on insect abundance and diversity, p. 271-284. In: A. D. Watt; N. E. Stork \& M. D. Hunter (eds). Forest and insects. London, Chapman and Hall, $345 \mathrm{p}$.

Wiegert, R. G. \& D. C. Coleman. 1970. Ecological signicance of the low oxygen consumption and high fat accumulation by Nasutitermes costalis (Isoptera: Termitidae). Bioscience 20: 663-665.

Wood, T. G. \& W. A. Sands. 1978. The role of termites in ecosystems, p. 245-292. In: M. V. Brian (ed). Production ecology of ants and termites. Cambridge, Cambridge University Press, $350 \mathrm{p}$.

Wood, T. G.; R. A. Johnson; S. Bacchus; M. O. Shittu \& J. M. Anderson. 1982. Abundance and distribution of termites (Isoptera) in a riparian forest in the Southern Guinea savanna vegetation zone of Nigeria. Biotropica 14: 25-39. 